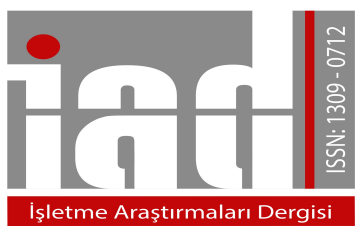

Journal Of

Business Research

Turk

www.isarder.org

\title{
The Impact of Workers' Remittances on Financial Market Development: A Case Study for Developing Countries
}

\author{
Burçak POLAT \\ Siirt University \\ Faculty of Business and Economics \\ Department of Economics \\ Siirt, Turkey \\ orcid.org/0000-0002-3290-064X \\ burcakpolat@hotmail.com
}

\begin{abstract}
Although workers' remittances inflows have grown gradually over the years and showed a sharp rise after 2000's in the developing countries; the effect of remittances on financial development did not receive deserved attention from academic scholars. Yet, the effect of remittances on financial development is very important issue as the financial development plays very important role in rising economic growth or reducing poverty. Thus, main objective of this study is to explore the possible effects of workers remittances on financial market developments by employing dynamic panel data method for the period from 2002 to 2014. Our empirical results prove that there is no significant correlation between financial developments and remittance inflows. Yet, we have found that financial developments are positively correlated with investments while they are negatively correlated with inflation and economic growth.
\end{abstract}

Keywords: Financial Development, Remittances, International Migration, Financial Markets, Dynamic Panel Data

\section{1- Introduction}

Workers remittances account for the second largest capital inflows into developing countries after foreign direct investments (FDI) in recent years. World Bank (2009) has reported that remittances showed a stable and dramatic growth from U.S. $\$ 3.3$ billion in 1975 to U.S. \$289.4 billion in 2007 . When we analyze inflows of remittances from developed countries to developing countries, we see that they grow gradually from 1970s to 2000s. But, after 2000s, this growth has accelerated and reached peak levels in 2007s.

As the second largest capital flows, remittances received noticeable attention from scholars in recent years. Thus, there is an abundant literature regarding the effect of workers remittances on economic growth, education, infant mortality or 
entrepreneurship, yet, there is almost a handful of study analyze the question of whether remittances promote financial market development or not. Notably, the impact of workers remittances on financial market developments are extremely important issue since financial developments play an important role to foster growth or reduce the poverty. Furthermore, financial market developments may also affect the inflows of remittances and multiply the growth of remittances and economic growth.

A potential complication in measuring the effects of remittances on financial development is that there is an inverse causality among these two variables. In other words, while workers remittances enhance the financial development by increasing the loanable funds, development in financial market may lead higher amounts of remittances by reducing the cost of transferring remittances from developed countries to developing countries. Thus, there might be endogeneity bias in measurements if we don't consider the two-way causality between remittances and financial developments.

By employing dynamic panel data, the main objective of this study is therefore to find out the impact of remittances from developed countries to 29 developing countries ${ }^{1}$ from 2002-to 2014. The contribution of the study can be elaborated as follows: First study employs 29 developing countries that receive the largest portion of remittances over the developing countries in the world. Second, by employing one-step Generalized Method of Moments (GMM) dynamic panel data technique, we are able to capture reverse causality from financial market developments to the volume of remittances. Third, we are able to predict the determinants of remittances by employing other control variables to avoid omitted variable bias in data.

The rest of the paper is organized as follows: Second section summarizes the literature review. Following second section, third section describes the data and methodology employed. Fourth section presents the empirical results. And last section, concludes the study by suggesting policy implications.

\section{2- Literature Review}

There are a large number of researches dealing the possible effects of workers' remittances on economic growth, welfare of recipient country, poverty, education, health, income inequality at micro and macro level. For-example, by using micro datasets, the studies of Cox and Ureta (2003); Lopez Cordova (2004) and Adams (2004), Adam and Page (2005); Taylor et al. (2005) have investigated the possible effects of remittances on the education, health and poverty of the recipient countries. Furthermore, the studies of Sark et al. (1986a, 1986b); Milanovic, (1987); Taylor (1992); Taylor and Wyatt (1996); Barham and Boucher (1998); Docquier and Rapoport (2003) have analyzed the impact of remittances on income inequality in recipient country. Moreover, the studies examining the possible effects of remittances on economic growth can be listed as Chami et al. (3003); Caceres and Saca (2006); Mundaca (2008); Giuliano and Ruiz-Arranz (2009). Yet, the studies investigating the linkage between growth and remittances have found mixed evidence; some of them

1 Country List: Albania, Armenia, Azerbaijan, Belarus, Bolivia, Brazil, Bulgaria, China, Colombia, Dominican Rep., Egypt, Arab Rep., Georgia, Guatemala, India, Jamaica, Jordan, Kyrgyz Rep., Macedonia, Malaysia, Mauritius, Mexico, Moldova, Namibia, Peru, Philippines, Romania, Russia, Thailand. 
have found negative effect of remittances on growth while some others have found positive effect of remittances on growth.

Following the studies examine only relationship between remittances and growth, some researchers have attempt to consider the effect of financial market development on the growth process. The studies of Mundaca (2009); Gupta et al (2009); Masuduzzaman (2014) have analyzed the effects of remittances on growth or poverty by considering the effect of financial development. The study of Mundaca (2009) has claimed that positive responsiveness of economic growth to remittances accelerates due to the developments in financial intermediations. Furthermore, the study of Gupta et al. (2009) has assessed the effect of remittances inflows in Sub-Saharan Africa on poverty and financial development. They have argued that remittances have a direct poverty-mitigating effect and promote financial developments.

Yet, there is a few study analyses the effects of remittances on financial developments. Recent studies of Aggarwal et al. (2011) and Masuduzzaman (2014) have investigated the linkages between workers' remittances and financial development by claiming that financial developments have growth-enhancing and poverty-reducing effects. The study of Aggarwal et al. (2011) has investigated the effects of remittances flows into 119 developing countries on financial developments. They have proved that remittance flows promote financial developments in this country group. The study of Masuduzzaman (2014) has investigated the long-run relationship between growth and remittances and long-run relationship between remittances and financial development in Bangladesh. Similarly, he has also concluded that remittances promote financial developments in the long-run in Bangladesh.

\section{3- Data and Methodology}

\subsection{Data}

We have selected three different variables as proxy for financial market development. First measurement is broad money as the percentage of Gross Domestic Product (GDP) that is prefixed as financial development1. World Bank define broad money as "Broad money is the sum of currency outside banks; demand deposits other than those of the central government; the time, savings, and foreign currency deposits of resident sectors other than the central government; bank and traveler's checks; and other securities such as certificates of deposit and commercial paper." Second measure for financial development is determined as domestic credit provided by financial sector as percentage of GDP. We prefixed this second proxy for financial development as financial devleopment2. Domestic credit provided by financial sector refers all types of credits to both private and public sectors except credits to central Bank. Lastly we have specified domestic credit to private sector as percentage of GDP as third proxy for financial development and we prefixed it as financial development3. Domestic credit to private sector includes all types of financial resources provided by both private and public financial corporations. As the main interest of explanatory variable we have selected workers remittance inflows into the selected developing country group. Furthermore, we have also incorporated control variables to avoid omitted variable bias. Control variables can be listed as follows: Openness index, gross capital formation (investment), lending interest rate, and inflation and growth rate of GDP. Openness index is simply equals to the ratio of summation of exports and imports to GDP. All variables are measured in US Dollars and have been obtained from World Bank data 
retrieval tool (www. worldbank.org.). Moreover, we have also included time dummies to capture the time effect, if any, on financial market development. Descriptive statistics of the data and their expected signs are provided in Table 1.

Table.1 Summary and Descriptive Statistics

\begin{tabular}{|l|c|c|c|c|}
\hline Variables & Observations & Mean & $\begin{array}{c}\text { Standard } \\
\text { Deviation }\end{array}$ & $\begin{array}{c}\text { Expected } \\
\text { Sign }\end{array}$ \\
\hline $\begin{array}{l}\text { Financial } \\
\text { Development1 (\%) }\end{array}$ & 364 & 61.2960 & 36.9073 & - \\
\hline $\begin{array}{l}\text { Financial } \\
\text { Development2 (\%) }\end{array}$ & 364 & 57.4117 & 36.6716 & - \\
\hline $\begin{array}{l}\text { Financial } \\
\text { Development3 (\%) }\end{array}$ & 364 & 30.0676 & 30.0674 & - \\
\hline Remittances & 364 & 5.2588 & 10.1224 & + \\
\hline Openness & 364 & 84.9459 & 36.4699 & + \\
\hline Investment (\%) & 364 & 25.2764 & 11.0217 & + \\
\hline Interest Rate (\%) & 364 & 14.6117 & 8.6968 & + \\
\hline Inflation (\%) & 364 & 6.3945 & 6.5379 & - \\
\hline Growth (\%) & 364 & 5.0130 & 4.1588 & - \\
\hline
\end{tabular}

As one may observe from Table 1, we don't have any missing observations in the data. By analyzing the mean and standard deviations of variables, we may extract that financial development 1 which refers to broad money in the financial market has the highest mean value as expected. In terms of standard deviation values, both financial developement 1 and financial development2 are the most volatile variables in the dataset. Meaning that, developing countries are subject to different levels of broad money and domestic credit provided by financial sectors. This difference may be the result of different financial market policies take place in this county group.

\subsection{Methodology}

The structure of dataset necessitates employing dynamic framework of panel data rather than employing traditional panel data. Economic growth by its' very nature shows a dynamic structure. But, most importantly there might be reverse causality from growth to workers' remittances. Thus, traditional panel data models such as Fixed Effects (FE) or Radom Effects (RE) don't solve the endogeneity problem between growth and remittances and produces biased estimators. To avoid endogeneity bias, we have used lagged values (second or higher order) of regressors as instruments in GMM method as suggested by Arellano Bond and Bover (1995). Our main model can be written as:

$$
F D^{K}{ }_{i, t}=\alpha F D^{K}{ }_{i, t-1}+\beta_{1} \operatorname{Re} m_{i, t}+\beta_{2} X_{i, t}+a_{i}+u_{i, t}
$$

In equation $1, F D$ indicates financial developments, i subscript refers to country and $t$ subscript refers to time period from 2002 to 2014. Furthermore, K represents three types of financial developments so that $K=1$ represents financial development1, $K=2$ represents financial development 2 and $\mathrm{K}=3$ represents financial development 3 respectively. On right hand side of the equation (1), $F D_{i, t-1}$ refers the lagged value of dependent variables while $\operatorname{Re} m_{i, t}$ refers to workers' remittances into the developing 
countries in the analysis and $X_{i, t}$ refers to other control variables. Moreover, $a_{i}$ represents country or (fixed) effect and $u_{i, t}$ represent the error term respectively.

By taking the first difference of the equation 1, we may deduct the country effect from the regression so that our main specification can be written as:

$$
F D^{K}{ }_{i, t}-F D^{K} i_{t-1}=\alpha\left(F D^{K}{ }_{i, t-1}-F D^{K}{ }_{i, t-1}\right)+\beta_{1}\left(\operatorname{Re} m_{i, t}-\operatorname{Re} m_{i, t-1}\right)+\beta_{2}\left(X_{i, t}-X_{i, t-1}\right)+u_{i, t}-u_{i, t-1}
$$

Yet, in Equations 1 and 2, we still need to use instruments to deal with the endogenetiy between especially growth and remittances. As clearly seen in equation 2, we may omit country effect from the regression, but lagged value of dependent variable might be still correlated with the lagged value of the error term and produce biased estimators.

By relying on three assumptions, following moment conditions can be applied to obtain unbiased estimators: (a) we assume that error term is serially uncorrelated and identically independently distributed (i.i.d); (b) explanatory variables are weakly exogenous; (c) there is no correlation between lagged values of explanatory variables and country specific effect.

As we can use lagged (two or higher order) values of explanatory variables as instruments, we may obtain following moment conditions:

$$
\begin{aligned}
& E\left[F D^{K}{ }_{i, t-s}\left(u_{i, t}-u_{i, t-1}\right)=0 \quad \text { for } \mathrm{s} \geq 02 ; \mathrm{t}=3, \ldots \ldots \ldots \ldots \ldots \mathrm{T} \text { and } \mathrm{K}=1,2,3\right. \\
& E\left[\operatorname{Re} m_{i, t-s}\left(u_{i, t}-u_{i, t-1}\right)\right]=0 \quad \text { for } \mathrm{s} \geq 02 ; \mathrm{t}=3, \ldots \ldots \ldots \ldots \ldots \mathrm{T} \\
& E\left[X_{i, t-s}\left(u_{i, t}-u_{i, t-1}\right)\right\rfloor=0 \quad \text { for } \mathrm{s} \geq 02 ; \mathrm{t}=3, \ldots \ldots \ldots \ldots \ldots \mathrm{T} \\
& E\left[F D^{K}{ }_{i, t-s}-F D^{K}{ }_{i, t-s-1}\left(a_{i}+u_{i, t}\right)=0 \text { for } \mathrm{s}=1\right. \\
& E\left[\operatorname{Re} m_{i, t-s}-\operatorname{Re} m_{i, t-s-1}\left(a_{i}+u_{i, t}\right)\right]=0 \text { for } \mathrm{s}=1 \\
& E\left[X_{i, t-s}-X_{i, t-s-1}\left(a_{i}+u_{i, t}\right)\right\rfloor=0 \quad \text { for } \mathrm{s}=1
\end{aligned}
$$

The process from Equation 1 till Equation 9, is so called as difference GMM model. Yet, if the explanatory variables are not weakly exogenous, we may apply additional moment conditions by taking the lagged of instruments. This later process is so called as system GMM model. To ensure the robustness of our estimators, we have employed one-step system GMM to obtain unbiased estimators. Even though, system GMM produces more precise results compared to difference GMM model, it has also some pitfalls. As we employ additional moment conditions, we increase the number of instruments and may encounter over-identification problem among instruments. To avoid this problem, we have used Roodman's (2009) reduction technique to collapse number of instruments. Furthermore, we have also carried on Hansen Test suggested by Hansen (1982) which is called as $J$ test as well to check if there is any overidentification problem among instruments.

\section{4- Empirical Results}

By employing three different one-step GMM specifications for three dependent variables, we have measured the impact of workers' remittances on financial market 
development from 2002 to 2014. Estimation results of each specification are prefixed as GMM1, GMM2 and GMM3 in Table 2. As seen from Table 2, lagged values of three dependent variables are significant ensuring the dynamic structure of the data. Furthermore, we have reported the post-estimation results at the bottom of Table 2 to understand if our estimations are robust or not. From, Arellano Bond AR (2) Test and Hansen Test statistics, we may confirm that there is no second order correlation in error terms or over-identification problems in terms of number of instruments.

Table.2 Estimation Results for Developing Country Group

\begin{tabular}{|c|c|c|c|}
\hline Variables & GMM1 & GMM2 & GMM3 \\
\hline Financial Development $1_{t-1}$ & $\begin{array}{l}0.9957 \\
(0.000)^{* *}\end{array}$ & $\longrightarrow$ & $\longrightarrow$ \\
\hline Financial Development2 $\mathrm{t}-1$ & 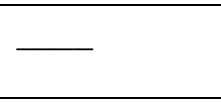 & $\begin{array}{r}0.9321 \\
(0.000)^{* *} \\
\end{array}$ & 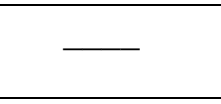 \\
\hline Financial Development $3 \mathrm{t}-1$ & - & $\ldots$ & $\begin{array}{l}0.9383 \\
(0.000)^{* *}\end{array}$ \\
\hline Remittances & $\begin{array}{l}0.0065 \\
(0.775)\end{array}$ & $\begin{array}{l}0.0133 \\
(0.513)\end{array}$ & $\begin{array}{l}-0.0250 \\
(0.142)\end{array}$ \\
\hline Openness & $\begin{array}{l}0.0064 \\
(0.546)\end{array}$ & $\begin{array}{l}0.0119 \\
(0.513)\end{array}$ & $\begin{array}{l}0.0051 \\
(0.628)\end{array}$ \\
\hline Investment & $\begin{array}{l}0.0528 \\
(0.029)^{*}\end{array}$ & $\begin{array}{l}0.1387 \\
(0.032)^{*}\end{array}$ & $\begin{array}{l}0.1768 \\
(0.001)^{* *}\end{array}$ \\
\hline Interest Rate & $\begin{array}{l}0.0528 \\
(0.041)^{*}\end{array}$ & $\begin{array}{l}-0.0114 \\
(0.806)\end{array}$ & $\begin{array}{l}-0.0160 \\
(0.821)\end{array}$ \\
\hline Inflation & $\begin{array}{l}-0.1523 \\
(0.020)^{*}\end{array}$ & $\begin{array}{l}-0.2004 \\
(0.002)^{* *}\end{array}$ & $\begin{array}{l}-0.2327 \\
(0.000)^{* *}\end{array}$ \\
\hline Growth & $\begin{array}{l}-0.1373 \\
(0.045)^{*}\end{array}$ & $\begin{array}{l}-0.0759 \\
(0.326) \\
\end{array}$ & $\begin{array}{l}-0.0567 \\
(0.241) \\
\end{array}$ \\
\hline Dummy for 2002 & - & $\longrightarrow$ & 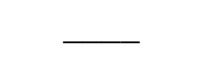 \\
\hline Dummy for 2003 & $\begin{array}{l}1.0176 \\
(0.460)\end{array}$ & $\begin{array}{l}-0.0121 \\
(0.994)\end{array}$ & $\begin{array}{l}-2.4512 \\
(0.051)^{*}\end{array}$ \\
\hline Dummy for 2004 & $\begin{array}{l}-1.0076 \\
(0.460)\end{array}$ & $\begin{array}{l}-1.9818 \\
(0.222)\end{array}$ & $\begin{array}{l}-2.4963 \\
(0.017)^{* *}\end{array}$ \\
\hline Dummy for 2005 & $\begin{array}{c}-0.7464 \\
(0.383)\end{array}$ & $\begin{array}{l}-0.8593 \\
(0.596)\end{array}$ & $\begin{array}{l}-2.4035 \\
(0.013)^{* *}\end{array}$ \\
\hline Dummy for 2006 & $\begin{array}{l}0.2990 \\
(0.748)\end{array}$ & $\begin{array}{l}-2.1815 \\
(0.111)\end{array}$ & $\begin{array}{l}-2.4165 \\
(0.013)^{* *}\end{array}$ \\
\hline Dummy for 2007 & - & 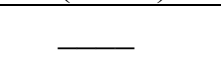 & - \\
\hline Dummy for 2008 & $\begin{array}{l}-2.3046 \\
(0.008)^{* *}\end{array}$ & $\begin{array}{l}0.0785 \\
(0.950)\end{array}$ & $\begin{array}{l}-1.1517 \\
(0.254)\end{array}$ \\
\hline Dummy for 2009 & $\begin{array}{l}2.8882 \\
(0.145)\end{array}$ & $\begin{array}{l}0.8318 \\
(0.695)\end{array}$ & $\begin{array}{l}-1.6214 \\
(0.347)\end{array}$ \\
\hline Dummy for 2010 & $\begin{array}{l}-1.6892 \\
(0.031)^{*}\end{array}$ & $\begin{array}{l}-1.1373 \\
(0.337)\end{array}$ & $\begin{array}{l}-2.6517 \\
(0.008)^{* *}\end{array}$ \\
\hline Dummy for 2011 & $\begin{array}{l}-1.1486 \\
(0.246) \\
\end{array}$ & $\begin{array}{l}-0.3504 \\
(0.752) \\
\end{array}$ & $\begin{array}{l}-1.8245 \\
(0.056)^{*}\end{array}$ \\
\hline Dummy for 2012 & $\begin{array}{l}-1.4675 \\
(0.089) \\
\end{array}$ & $\begin{array}{l}0.9252 \\
(0.496)\end{array}$ & $\begin{array}{l}-1.5079 \\
(0.189) \\
\end{array}$ \\
\hline
\end{tabular}




\begin{tabular}{|l|l|l|l|}
\hline Dummy for 2013 & $\begin{array}{l}0.8757 \\
(0.396)\end{array}$ & $\begin{array}{l}0.7302 \\
(0.645)\end{array}$ & $\begin{array}{l}-1.3900 \\
(0.230)\end{array}$ \\
\hline Dummy For2014 & -0.9009 & -0.0183 & -1.7943 \\
& $(0.391)$ & $(0.992)$ & $(0.195)$ \\
\hline Wald Test $\mathrm{Ch}^{2}(20)$ & 51066.59 & 18699.88 & 24294.40 \\
Prob>Ch & $(0.000)^{* *}$ & $(0.000)^{* *}$ & $(0.000)^{* *}$ \\
\hline Arellano Bond AR (2) Test & & 0.890 & 0.377 \\
\hline Hansen test & 0.689 & & 0.460 \\
\hline Number of Instrument & 0.807 & 38 & 38 \\
\hline Number of Observations & 336 & 336 & 336 \\
\hline
\end{tabular}

Note: while * refers to $\% 1$ significance level, ${ }^{* *}$ refers to $\% 5$ significance level. Probability values of standard errors are given in the parenthesis.

As we analyze the Table 2, we can clear observe that workers' remittance inflows do not have any significant effect on three measures of the financial market developments (financial development1, 2 and 3). Yet, we have found that investment and inflation variables have robust significant effect to explain the three types of financial developments in GMM1, GMM2 and GMM3 specifications respectively. While investment is positively correlated with financial developments, inflation is negatively correlated with financial developments. In other words, broad money including deposits and savings, credits to private sectors and all types of credits provided by financial sectors are likely to increase as the amount of investments rise in this country group. As the demand for loanable funds rise to finance the investments, supply of loanable funds and therefore amount of savings increase as well to meet the excess demand. Meaning that, investors' demand for funds motivates both deposit holders and financial institutions to improve their activities to meet excess demand in the financial market. On the other side, higher inflation rates have deterring effect on financial developments. Since, lending interest rates are adjusted according to the inflation rates by all financial institutions, negative impact of inflation rate on loanable funds and broad money in market is unavoidable. In other saying, an increase in inflation rates leads also increase in lending interest rates and therefore reduces the demand for loanable funds from investors. As demand for loanable funds decreases, financial institutions and deposit holders are likely to reduce their savings.

Furthermore, we have proved that higher interest rates and growth rates have power to predict the broad money as percentage of GDP in GMM1 specification. While interest rate is positively correlated with financial development1, growth rate is negatively correlated with financial development 1 . In other words, broad money which includes all types of deposits and savings responds to an increase in interest rates positively but it responds to an increase in growth rate negatively. The possible interpretation of this result can be explained as follows: First, as lending interest rates get higher, deposit holders are likely to increase their savings to earn more interest income on their savings. Thus, broad money in the market except money in central bank and other financial institutions are likely to increase as lending interest rates increase. Even though, we could not find any effect of lending interest rate on financial development 2 and financial 3 which refers to credits to private sector and credits by financial institutions are likely to be affected in the long-run. We believe that as all kinds of savings except central bank and financial institutions have the opportunity to receive loanable funds from deposit holders in the long-run. Thus, we may claim that an 
increase in lending interest rate may rise loanable funds in the market. On the other side, growth rate is found to have a significant negative effect on the broad money (financial development1). As Solow (1974) growth theory suggest, countries that converge to the steady state point have lower interest rates. He has argued that developed countries that have higher growth rates have lower interest rates. Depending on the argument of Solow (1074), we may argue that as growth rate of countries reduce lending interest rates and demotivate deposit holders to save more. Again, even though, we could not find any effect of growth rates on financial development 2 and financial development 3 , we may conclude that both types of financial developments are also likely to be affected from higher growth rates in the long-run.

Though, we have separate financial developments into three groups, we may rely on the estimation results of financial development1 (GMM1) which refers to the broad money in the market. The reason is that broad money refers to all types of savings and deposits in the market except in financial institutions and central bank. Thus, economic variables that affect broad money may affect other types of financial developments in the long-run even if these variables do not have any effect on them in the short-run.

Furthermore, we have proved that Global Financial Crises (GFC) that emerged at the end of 2007 due to the collapse of real estate property in USA has a deterring effect on financial market development1 (broad money). This result again does not come up a surprise, as many scholars have argued that GFC have affected the economies of developing countries through financial markets.

\section{5- Summary and Concluding Remarks}

Although workers' remittances inflows have grown gradually over the years and showed a sharp rise after 2000's in the developing countries; the effect of remittances on financial development did not receive enough attention from academic scholars. Yet, the effect of remittances on financial development is very important issue as the financial development plays very important role in rising economic growth or reducing poverty. Thus, main objective of this study was to explore the possible effects of workers remittances on financial market developments by employing one-step system GMM approach for the period of 2002 -2014. Novelty of the study is three folds: First, we have included developing countries classified by World Bank as higher or lower middle income countries that receive the most portions of remittances. Second, we have captured the inverse causality from remittances to financial growth by employing dynamic panel data model (one-step system GMM). Third, we have included additional control variable to reduce the omitted variable problem to predict the other determinants of financial development.

At the end of our study, we empirically proved that all three types of proxies for financial development (financial devlopment1, financial development 2 and financial development3) have not affected from remittances. Yet, we have found out that, while the amount of investments has significant positive effects on three types of financial developments but inflation has significant negative effect on them. Meaning that, as demand for loanable funds rise, deposit holders outside of banks, banks and other financial institutions will respond positively to meet the excess demand in markets. Furthermore, financial institutions and deposit holder adjust interest income according to inflation rates to avoid loss due to higher inflation. Thus, an increase in inflation rates 
leads to investors to demand less for loanable funds, so that in return, leads a reduction in the supply of loanable funds.

Moreover, broad money (financial development1) including all types of deposits and saving other than banks are affected negatively from growth but affected positively from higher interest rates. Though, the effect of growth and lending interest rate seem to not have any effects on financial development 2 and financial development 3 in shortrun, we believe that changes in broad money due to changes in growth rates or interest rates affect the deposits to private sectors (financial development2) or deposits provided by financial sectors (financial development3) in the long-run. Thus, the results of GMM1 may be accepted as the main specification to predict the effects of control variables on financial development in the long-run.

The interpretation regarding the effects of growth and interest rates on broad money is as follows: First, higher interest rates increase the possibility of income on savings thus, increase the level of broad money in the market. Yet, higher growth rate is associated with lower interest rates and thus reduce the willingness of deposit holders to save more.

The policy implications are worthy to note: event though higher lending interest rates have a positive effect on broad money in short-run, it may affect the amount of investments negatively in the long-run. Thus, central banks of this country group should take care of short-run and long-run effects of interest rates on the amount of savings (deposit holders) and investments.

\section{REFERENCES}

Adams, R.H.Jr. (2004). Remittances and poverty in Ghana. World Bank Policy Research Paper 3838. Washington, DC.

Adams, R.H.Jr. and Page, J. (2005). Do international migration and remittances reduce poverty in developing countries? World Development, 33 (10): 1645-1669.

Aggarwal, R., Demirguc-Kunt, A., and Peria, M.S.M. (2011). Do workers' remittances promote financial development? Journal of Development Economics, 96: 255264.

Arellano, M. and O. Bover. (1995). Another Look at the Instrumental Variable Estimation

Error Components Model. Journal of Econometrics 68, no. 1 (1995): 29-51.

Barham, B. and Boucher, S. (1998). Migration, remittances and the household in Africa: A review of evidence. Journal of African Economies, 15(2): 426-462.

Caceres, L.R. and Saca, N.N. (2006). What do remittances do? Analyzing the private remittance transmission mechanism in El Salvador. IMF Working Paper 06/250, Washington, DC.

Chami, R., Fullenkamp, C. and Jahjah, S. (2003). Are immigrant remittance flows a source of capital for development? IMF Working Paper 03/189. Washington, DC.

Cox E.A. and Ureta, M. (2003). International migration, remittances and schooling: Evidence from El Salvador, Journal of Development Economics, 72: 429-461. 
Docquier, F. and Rapoport, H. (2003). Remittances and inequality: A dynamic migration model. IZA Discussion Paper 808, Bonn, Germany.

Giuliano, P. and Ruiz-Arranz, M. (2009). Remittances, financial development, and growth. Journal of Development Economics, 90: 144-152.

Gupta, S.; Patitillo, C.A. and Wagh, S. (2009). Effect of remittances on poverty and financial development in Sub-Saharan Africa. World Development, 37 (1): 104115.

Hansen, L.P (1982). Large sample properties of Generalized Method of Moment Estimators.

Econometrica, 50(4), 1029-1054

Lopez Cordova, E. (2005). Globalization, migration and development: The role of the Mexican migrant remittances. Economia, 6: 217-249.

Mundaca, G. (2008). Remittances, financial market developments, and economic growth: The case of Latin America and the Caribbean. Review of Development Economics, 13(2):288-303.

Masuduzzaman, M. (2014). Workers' remittances inflow, financial development and economic growth: A study on Bangladesh. International Journal of Economics and Finance, 6(2): 247-266.

Milanovic, B. (1987). Remittances and income distribution. Journal of Economic Studies, 14: 23-37.

Stark, O., Taylor, J.E., and Yitzhaki, S. (1986a). Remittances and inequality, Economic Journal, 28: 309-322.

(1986b). Migration, remittances and inequality: A sensitivity analysis using the extended gini index. Journal of Development Economics, 28: 309-322.

Taylor, J.E. (1992). Remittances and inequality reconsidered: Direct, indirect and intertemporal effects. Journal of Policy Modeling, 14: 187-208.

Taylor, J.E. and Wyatt, T.J. (1996). The shadow value of migrant remittances, income and inequality in a household-farm economy. Journal of Development Economics, 32: 899-912.

Taylor, J.E.; Jorge, M.; Adams, R. and Alejandro, L.-F. (2005). Remittances, inequality and poverty. Evidence from rural Mexico. Working Papers 60287. University of California, Davis, Department of Agricultural and Resource Economics.

Roodman, D. (2009). How to do xtabond 2: an introduction to difference and system GMM in stata. The Stata Journal, 9 (1): 86-136. 